\title{
Comparative ecology of nekton residing in a tidal creek and adjacent seagrass meadow: community composition and structure
}

\author{
Michael P. Weinstein ${ }^{1,2}$ and Hugh A. Brooks ${ }^{2}$ \\ 1 Department of Biology, Virginia Commonwealth University, Richmond, Virginia 23284, USA \\ 2 Virginia Institute of Marine Science and School of Marine Science, College of William and Mary, Gloucester Point, \\ Virginia 23062, USA
}

\begin{abstract}
A structural analysis of the nekton communities occupying a tidal creek and adjacent seagrass meadow at Vaucluse Shores, Virginia (Delmarva Peninsula, USA) is presented along with a comparison of the relative value of each habit to the early life stages of marine and estuarine species. Seagrass meadows were characterized by significantly greater richness and diversity of constituent taxa; both areas, nevertheless, contained mixtures of habitat specialists and wide-ranging (ubiquitous) species that displayed no areal preferences. Except for a few resident forms, much of the nekton community in the grassbed was comprised of less abundant 'southern' species that entered the Chesapeake Bay in late summer and fall. Reciprocal averaging and numerical classification procedures applied to pooled station collections further indicated the clinal nature of species distributions among habitats, but also clearly demonstrated several microhabitat associations for either the Zostera marina or Ruppia maritima portions of the grassbed. The sciaenid, Leiostomus xanthurus dominated the nekton in both habitats, with $>80 \%$ of all individuals but were nearly 4 times as abundant in the tidal creek. Abundance distribution and length frequency analyses for this species indicated that the marsh is the preferred habitat but also that larger individuals in the population continuously 'bled off' into downstream areas. Two other species of regional importance, Callinectes sapidus and Paralichthys dentatus, also utilized both habitats extensively. Late in summer and early fall, juveniles of both species were more abundant in the grassbed, whereas earlier in the year, they were randomly dispersed. The apparently limited dependence on both the grassbed and tidal creek by the young of local taxa is strikingly different when compared to similar habitats at lower latitudes. In light of the differences established between these habitats and their utilization by different species, an attempt is made to identify potentially important determinants of community structure and relate these to the success of individual populations in both areas. Because few experimental data are available, our presentation, by necessity, is hypothetical.
\end{abstract}

\section{INTRODUCTION}

Nekton communities of the shore zone of estuaries are unique. At middle and higher latitudes there are periodic inundations of the shallows by the progeny of many species that are spawned hundreds of kilometers (or more) from the areas in which they eventually reside. These species are transient in the sense that they are only part-time residents of the habitat, yet, on a seasonal basis, can frequently dominate the com-

Contribution No. 1082 Virginia Institute of Marine Science munity (e.g. Weinstein et al,, 1980). Further, their populations are characterized by exceptionally high turnover rates due to immigration and emigration from the residence zones (Arnoldi et al., 1974; Yakupzack et al., 1977; Knudsen and Herke, 1978).

Despite the ephemeral nature of the nekton assemblage and the expectedly high turnover rate of its constituent populations, there are recognizable nekton communities associated with individual habitats. Much of the individuality of these communities is apparently derived from habitat selection (Rosenzweig, 1974) and perhaps by differential mortality of 
component species (thus, there may be a strong 'local' influence of predation). We can, therefore, recognize 'marsh' communities, 'seagrass' communities and others within the estuary. Although many of the common species (both resident and transient) are likely to be found throughout the estuary, and are often considered generalists with respect to habitat requirements, careful scrutiny of their distribution often shows clearly defined centers of abundance (Weinstein et al., 1980). Moreover, these distributions may be life-stage dependent and may vary with season. Substantial overlaps in species abundances then, occur among estuarine nekton communities, the differences among them are derived from the relative numbers of these common species, from a few specialized forms such as the cyprinodonts that frequent salt marshes, the pipefishes (Syngnathidae) of seagrass meadows, and a large variety of species of intermediate and rarer occurrence that occupy a particular habitat.

From another perspective, the nekton community is comprised largely of immature individuals (another unique characteristic?) and marshes and seagrass meadows have been frequently described as 'nursery' habitats for several species. Interestingly, there are virtually no studies which compare the relative value of these 2 habitats in terms of habitat utilization, growth rates or production. Partly for this reason, we have initiated a 1-yr effort to compare the relative importance of a tidal creek and adjacent seagrass meadow to the nekton occupying them. This effort will be accomplished within the framework of community composition and structure. We emphasize the preliminary nature of our effort because of the absence of critical information on turnover rates of individual populations, exchange of individuals between habitats and other parameters which would make such comparisons more complete. When these data are forthcoming, the conceptual framework we offer here can be strengthened and evaluated.

\section{MATERLALS AND METHODS}

The study area was situated at Vaucluse Shores, Virginia on the Chesapeake Bay shoreline of the Delmarva Peninsula (Fig. 1). Four sampling sites were established within a contiguous tidal creek-seagrass meadow ecosystem. One station was located at the entranceway, and a second near the head of a tributary of Hungars Creek (Fig. 1). These were designated Marsh Downstream and Marsh Upstream sampling stations, respectively. A roughly triangular 140 ha seagrass meadow was situated immediately to the west of the mouth of Hungars Creek. This site was partially enclosed by a sandbar along its western border which reached the shore at its northern terminus. A dredged channel (entering Hungars Creek) formed the southern border of the bed near its midpoint. The shallow upper end of the seagrass meadow consisted of a patchy, sand interspersed widgeon grass (Ruppia maritima) domi-
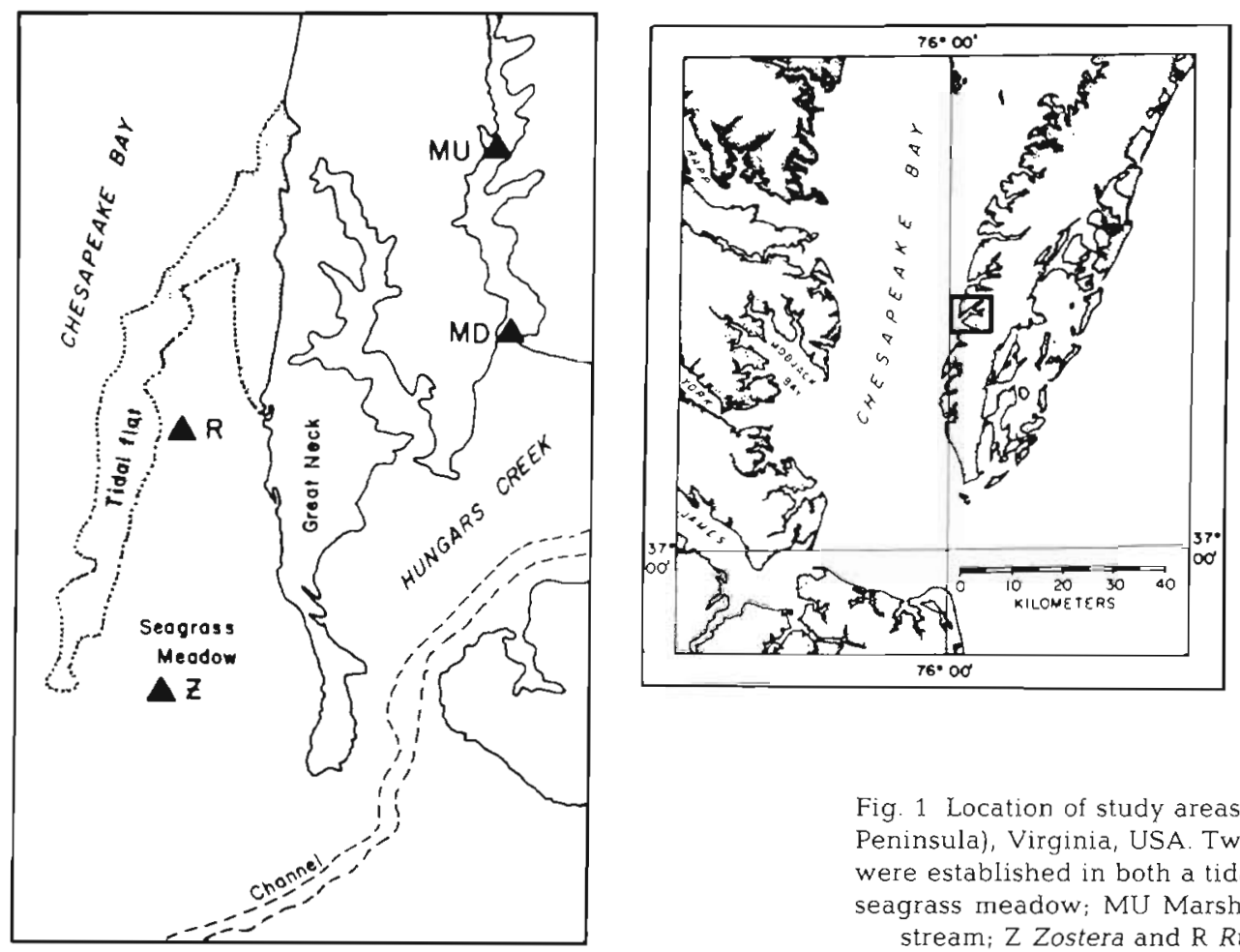

Fig. 1 Location of study areas at Vaucluse Shores (Delmarva Peninsula), Virginia, USA. Two permanent sampling stations were established in both a tidal creek tributary and a nearby seagrass meadow; MU Marsh Upstream; MD Marsh Downstream; Z Zostera and R Ruppia stations, respectively 
nated zone, which graded into dense, nearly homogeneous stands of eelgrass (Zostera marina) at the slightly deeper southern end. Two permanently marked sampling sites were established in the grass bed channel, one in the Ruppia dominated portion and a second 'downstream' in the denser Zostera stand.

All sampling was initiated during darkness near high tide. Nekton were collected by 2 methods. A $4.9 \mathrm{~m}$ semi-balloon otter trawl with wings and body of $19 \mathrm{~mm}$ mesh and a liner of $6.3 \mathrm{~mm}$ was towed at a speed of $1.03 \mathrm{~m} \mathrm{~s}^{-1}$ for $2 \mathrm{~min}$ at each station. In an earlier study at Vaucluse Shores, Orth and Heck (1980) demonstrated that 6 hauls of the trawl were necessary to attain asymptotic returns on community information (as judged by several diversity indices). Thus, a composite of 6 hauls was collected at each site in our study. It also was assumed that 6 hauls would be sufficient in the less diverse tidal creeks.

A modified Wegener ring (Wegener, 1976), $2.4 \mathrm{~m}$ in diameter, was used in depths less than $1 \mathrm{~m}$, immediately inshore of the trawling stations. The side walls of this gear consisted of $1.5 \mathrm{~mm}$ woven netting and the original design of the ring was changed to include a $305 \mathrm{~mm}$ 'skirt' and chain attached to the 'lead line' hoop which helped to fill contours along the bottom. Samples were collected by drifting over the site in total darkness and tossing the ring away from the direction of drift. Rotenone (Noxfish) was applied at a $30 \mathrm{ppb}$ concentration from a $5 \%$ formulation. Stricken fishes were collected by dipnet, when these ceased to surface, the area within the net was carefully swept in an overlapping pattern. Two Wegener ring samples were collected at each grassbed site, and because of limited footing in the tidal creek a single marsh collection was taken near each trawl station.

Nekton were preserved in $10 \%$ buffered formalin, and standard length (carapace width for crabs) was recorded for selected taxa. Up to 30 individuals per species were measured from each collection, subsampling for lengths was employed when sorted collections contained more than 30 individuals of a given species. Prior to each collection, temperature and salinity were recorded with an immersion thermometer and a temperature compensated refractometer, respectively.

For comparisons of nursery utilization, densities for all collections were reported as the number of individuals per $100 \mathrm{~m}^{2}$. The Wegener ring enclosed a fixed area of $4.7 \mathrm{~m}^{2}$. Area swept by the trawl was determined by measuring the horizontal distance across the open net mouth after trawling over a shallow sand bottom (Loesch et al., 1976; Kjelson and Johnson, 1978). This method, coupled with the distance traveled, resulted in a mean estimated area encompassed by the trawl of $627 \mathrm{~m}^{2}$.

\section{CLASSIFICATION ANALYSIS AND ORDINATION}

Numerical classification analysis used here is similar to the methods employed by Weinstein (1979) and Weinstein et al. (1980). Briefly, marsh and seagrass communities were compared by classification procedures using both 'normal' and 'inverse' classification schemes (Clifford and Stephenson, 1975). The former method groups sites by their species attributes while 'inverse' classification groups species according to their site of occurrence (i.e. the sites become the attributes of the species; Clifford and Stephenson, 1975). Similarity between sites or between species was calculated with the $C_{\lambda}$ index of Morisita (Morisita, 1959):

$$
C \lambda=\frac{2 \stackrel{S}{\Sigma} x_{i} y_{1}}{(\lambda x+\lambda y) X Y}
$$

where $s=$ number of species in the 2 samples; $x_{1}$ and $Y_{1}=$ number of individuals in the ith species in population $X$ and $Y_{i} X$ and $Y=$ total number of individuals in the 2 samples being compared; $\lambda x$ and $\lambda y=$ Simpson's (1949) measure of diversity for sampling with replacement

$$
\lambda x=\frac{\Sigma^{s} x_{1}^{2}}{X^{2}} \quad \lambda y=\frac{\Sigma^{s} y_{i}^{2}}{Y^{2}}
$$

For inverse analysis, $\mathrm{C}_{\lambda}$ was interpreted in terms of co-occurrence of species pairs across all station samples. Separate matrices were constructed for each comparison from untransformed, pooled monthly data and clustered by the flexible sorting strategy, with $\beta=$ -0.25 (Lance and Williams, 1967). Species represented by $<15$ individuals $(0.04 \%$ of the total catch) were eliminated prior to clustering (Weinstein et al., 1977). Trawl data alone were used in these analyses; dendrograms for site and species similarity were constructed and cross tabulated in a two-way coincidence table (Clifford and Stephenson, 1975).

Reciprocal averaging (RA) (Hill, 1973) is a weightedaverage ordination method effected by successive approximations of species scores in ordination space. Species are weighted by positions along a rough initial gradient and the weights are used to calculate initial sample scores. Successive 'back and forth' iterations (Gauch et al., 1977) lead to a stable, optimal solution of the primary data matrix that does not depend on the initial arrangement. Furthermore, ordination by species and samples is achieved simultaneously. The advantages of RA have been discussed by Gauch et al. (1977) and Del Moral (1980). The Cornell Ecology Program series, 'Ordiflex,' was used to extract principal axes from the original untransformed species-bysamples data matrix. 
Table 1. Pooled species abundance for all monthly trawl collections at grassbed (Zostera, Ruppia) and marsh sites at Vaucluse Shores, VA, listed in rank order

\begin{tabular}{|c|c|c|c|c|c|}
\hline $\begin{array}{l}\text { Zostera } \\
\text { Species }\end{array}$ & No. & $\%$ & $\begin{array}{l}\text { Ruppia } \\
\text { Species }\end{array}$ & No. & $\%$ \\
\hline Leiostomus xanthurus & 3794 & 61.7 & Leiostomus xanthurus & 3270 & 53.8 \\
\hline Callinectes sapidus & 1004 & 16.3 & Callinectes sapidus & 1409 & 23.2 \\
\hline Syngnathus fuscus & 753 & 12.2 & Syngnathus fuscus & 871 & 14.3 \\
\hline Anchoa mitchilli & 139 & 2.3 & Anchoa mitchilli & 104 & 1.7 \\
\hline Bairdiella chrysoura & 123 & 2.0 & Bairdiella chrysoura & 64 & 1.1 \\
\hline Apeltes quadracus & 105 & 1.7 & Paralichthys dentatus & 58 & 1.0 \\
\hline Paralichthys dentatus & 71 & 1.2 & Hypsoblennius hentzi & 53 & 0.9 \\
\hline Ophidion marginata & 36 & 0.6 & Ophidion marginata & 46 & 0.8 \\
\hline Hypsoblennius hentzi & 19 & 0.3 & Opsanus tau & 45 & 0.7 \\
\hline Opsanus tau & 15 & 0.2 & Centropristis striata & 33 & 0.5 \\
\hline Urophycis regia & 13 & 0.2 & Chasmodes bosquianus & 16 & 0.3 \\
\hline Tautoga onitis & 13 & 0.2 & Urophycis regia & 10 & 0.2 \\
\hline Eucinostomus argenteus & 12 & 0.2 & Gobiesox strumosus & 10 & 0.2 \\
\hline Centropristis striata & 8 & 0.1 & Lagodon rhomboides & 9 & 0.1 \\
\hline Orthopristis chrysoptera & 7 & 0.1 & Eucinostomus argenteus & 8 & 0.1 \\
\hline Sphoeroides maculatus & 7 & 0.1 & Stenotomus chrysops & 8 & 0.1 \\
\hline Gobiesox strumosus & 6 & 0.1 & Tautoga onitis & 7 & 0.1 \\
\hline Stenotomus chrysops & 5 & 0.1 & Anguilla rostrata & 6 & 0.1 \\
\hline Lagodon rhomboides & 4 & 0.1 & Trinectes maculatus & 6 & 0.1 \\
\hline Hippocampus erectus & 3 & $<0.1$ & Orthopristis chrysoptera & 6 & 0.1 \\
\hline Anguilla rostrata & 3 & $<0.1$ & Chilomycterus schoepfi & 5 & 0.1 \\
\hline Membras martinica & 3 & $<0.1$ & Chaetodon ocellatus & 5 & 0.1 \\
\hline Gobiosoma bosci & 2 & $<0.1$ & Conger oceanicus & 5 & 0.1 \\
\hline Syngnathus floridae & 2 & $<0.1$ & Brevoortia tyrannus & 3 & $<0.1$ \\
\hline Chilomycterus schoepfi & 2 & $<0.1$ & Syngnathus floridae & 3 & $<0.1$ \\
\hline Chasmodes bosquianus & 2 & $<0.1$ & Apeltes quadracus & 2 & $<0.1$ \\
\hline Trinectes maculatus & 2 & $<0.1$ & Membras martinica & 2 & $<0.1$ \\
\hline \multirow[t]{9}{*}{ Total } & $\overline{6153}$ & & Cynoscion nebulosus & 2 & $<0.1$ \\
\hline & & & Hippocampus erectus & 2 & $<0.1$ \\
\hline & & & Sphoeroides maculatus & 2 & $<0.1$ \\
\hline & & & Micropogonias undulatus & 1 & $<0.1$ \\
\hline & & & Diplodus holbrooki & 1 & $<0.1$ \\
\hline & & & Astroscopus guttata & 1 & $<0.1$ \\
\hline & & & Alosa aestivalis & 1 & $<0.1$ \\
\hline & & & Gobiosoma ginsburgi & 1 & $<0.1$ \\
\hline & & & Total & $\overline{6075}$ & \\
\hline Marsh Upstream & & & Marsh Downstream & & \\
\hline Species & No. & $\%$ & Species & No. & $\%$ \\
\hline Leiostomus xanthurus & 11307 & 89.5 & Leiostomus xanthurus & 14354 & 90.1 \\
\hline Callinectes sapidus & 661 & 5.2 & Callinectes sapidus & 1282 & 8.0 \\
\hline Brevoortia tyrannus & 390 & 3.1 & Anchoa mitchilli & 69 & 0.4 \\
\hline Anchoa mitchilli & 183 & 1.4 & Paralichthys dentatus & 68 & 0.4 \\
\hline Gobiosoma bosci & 29 & 0.2 & Trinectes maculatus & 48 & 0.3 \\
\hline Bairdiella chrysoura & 16 & 0.1 & Brevoortia tyrannus & 38 & 0.2 \\
\hline Trinectes maculatus & 16 & 0.1 & Anguilla rostrata & 36 & 0.2 \\
\hline Gobiosoma ginsburgi & 9 & 0.1 & Bairdiella chrysoura & 11 & 0.1 \\
\hline Anguilla rostrata & 7 & 0.1 & Syngnathus fuscus & 8 & 0.1 \\
\hline Micropogonias undulatus & 6 & $<0.1$ & Gobisoma bosci & 7 & $<0.1$ \\
\hline Mugil cephalus & 5 & $<0.1$ & Opsanus tau & 6 & $<0.1$ \\
\hline Paralichthys dentatus & 5 & $<0.1$ & Anchoa hepsetus & 2 & $<0.1$ \\
\hline Opsanus tau & 1 & $<0.1$ & Gobiosoma ginsburgi & 2 & $<0.1$ \\
\hline \multirow[t]{2}{*}{ Total } & $\overline{12634}$ & & Cynoscion regalis & 1 & $<0.1$ \\
\hline & & & Total & $\overline{15932}$ & \\
\hline
\end{tabular}




\section{RESULTS}

\section{Habitat comparisons}

As is true of most temperate latitude estuaries, a few species dominated the nekton collections. At marsh stations, Leiostomus xanthurus comprised nearly $90 \%$ of the total catch (number of individuals), while this percentage required the addition of Callinectes sapidus and Syngnathus fuscus in the seagrass habitats (Table 1). The latter species is considered a seagrass specialist and was only collected in the marsh both early and late in the year when windrows of detached Zostera were present. Transient species, i.e. those taxa recruited from offshore larval pools (Weinstein et al., 1980 ), constituted about $86 \%$ of the total number of individuals collected in all habitats and were dominated by $L$. xanthurus with slightly more than $80 \%$ of this total (Table 1).

Peak monthly catches (Fig. 2) were associated with the large influx of primarily Leiostomus xanthurus in the spring (April and May) and, on subsequent dates, decreasing abundance of this species probably reflected the effects of predation. There was, however, a mid-summer decline in total catch of all species associated with maximum water temperatures (Fig. 2, see also Fig. 6). As the shallows cooled beginning in late summer, a noticeable increase in catch occurred, due mainly to resident species returning to the area (probably from deeper portions of the system) and an influx of less common species from more southerly latitudes (see below).

Species richness was significantly greater (Wilcoxon sign-ranks test; $p<0.05$ ) at seagrass stations (Fig. 2) throughout the study period. In fact, a basic difference between the 2 habitats was the much higher species diversity associated with the structurally complex seagrass meadow. Within habitat differences in species composition and abundance also were evident in our data. These mainly took the form of seasonal changes in habitat utilization associated with seagrass coverage in the sampling areas. Early in the year (April-June) the lower portion of the bed was characterized by patchy coverage of seagrasses while the upper bed was only very sparsely covered (Weinstein and Brooks, own observ.). By late June the lower bed consisted of nearly homogenous stands of Zostera with nearly $100 \%$ coverage while the Ruppia dominated upper bed took on the patchy composition characteristic of the lower bed in spring. This change apparently affected the utilization of microhabitats by some of the dominant species (Figs. 3 and 4). Although the data are typically confounded by the contagious distribution of many species and the consequently large sampling errors, the patterns shown in Figs. 3 and 4 were very noticeable during the actual field sampling efforts Mean catch for Leiostomus xanthurus at the Zostera station during the months July through October, for
Fig. 2. Total number of individuals and species captured in monthly marsh creek and seagrass samples at Vaucluse Shores. Temperatures are maximum values recorded on each sampling date

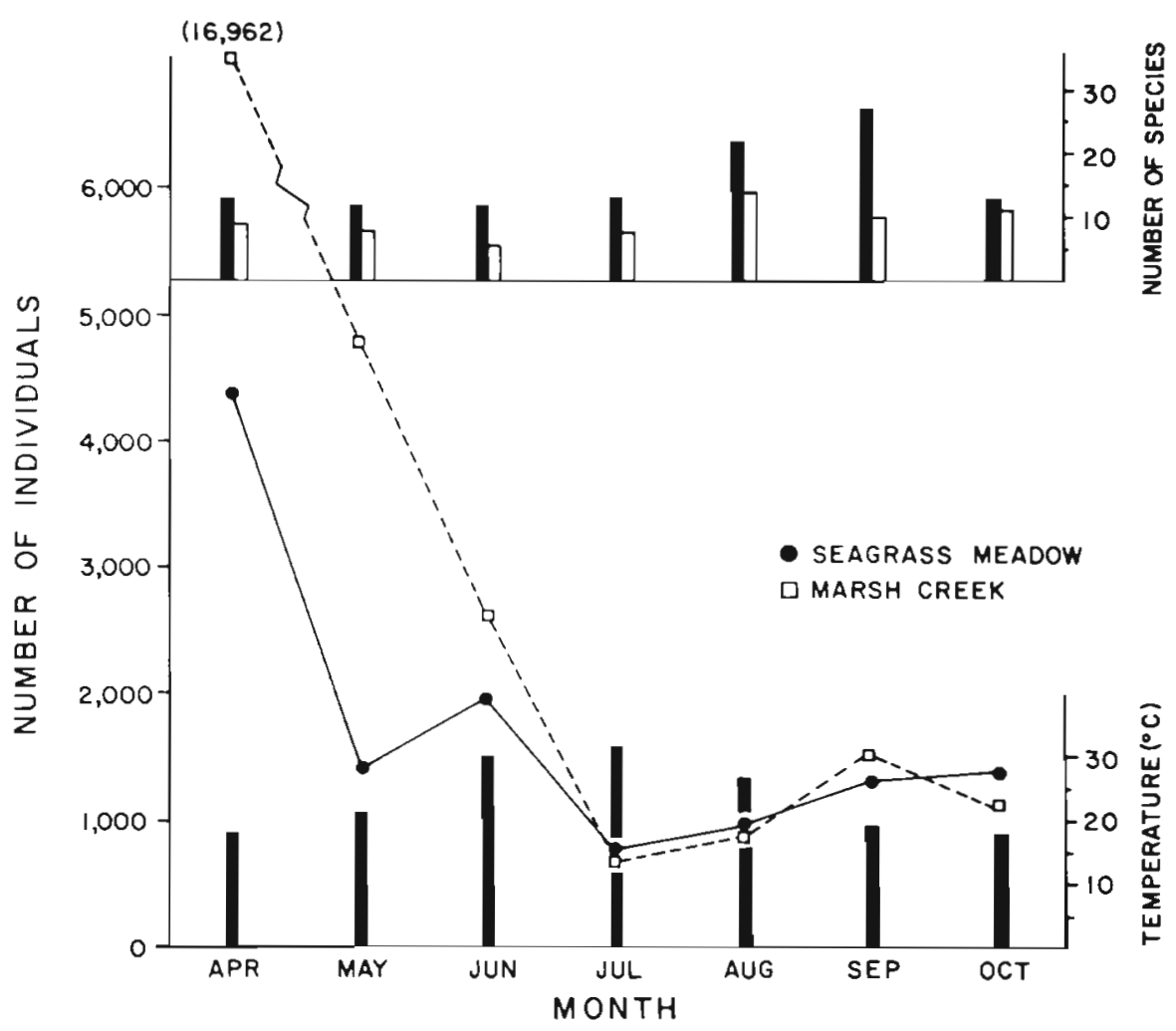




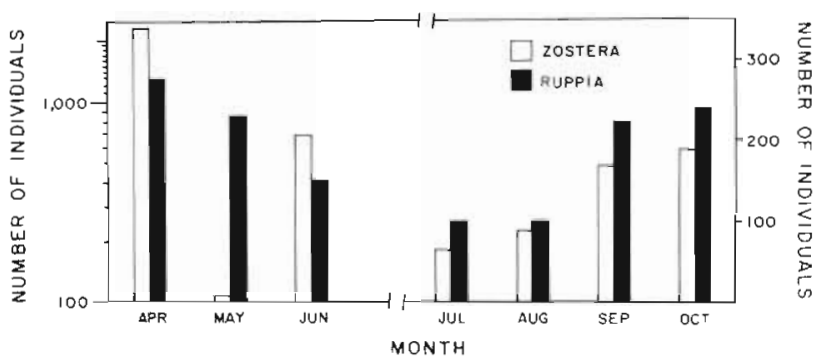

Fig. 3. Total numbers of spot (Leiostomus xanthurus) captured in monthly samples at stations located in either the Zostera or Ruppia portion of the grassbed study site. Densities for April through June are plotted logarithmically; thereafter all catches are shown on an arithmetic scale

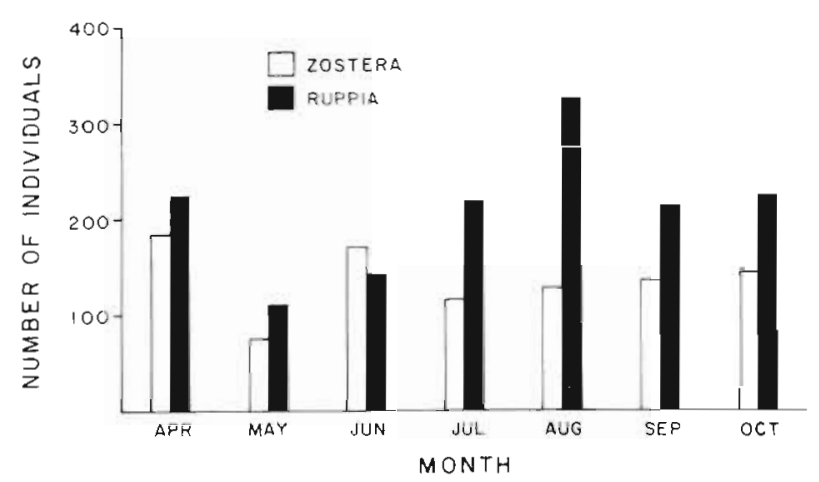

Fig. 4. Total numbers of blue crabs (Callinectes sapidus) captured in monthly samples at stations located in either the

Zostera or Ruppia portion of the grassbed study site example, was $127 \pm 62(\overline{\mathrm{X}} \pm \mathrm{SD})$ individuals while the corresponding catch at the Ruppia station was $167 \pm 75(\overline{\mathrm{X}} \pm \mathrm{SD})$ individuals. Comparable values for Callinectes sapidus at the 2 sites were $143 \pm 35$ $(\overline{\mathrm{X}} \pm \mathrm{SD})$ and $246 \pm 55(\overline{\mathrm{X}} \pm \mathrm{SD})$, respectively. Other species also displayed apparent preferences for a particular habitat and, in some instances, for a distinct microhabitat. These data, along with a summary of community patterns, are presented in Fig. 5 and Table 2.

\section{Community relationships}

We have employed 2 independent procedures to examine community structure. Reciprocal averaging, an indirect ordination method (Hill, 1973) and numeriCal classification (Clifford and Stephenson, 1975) were used to describe species and site relationships for pooled collections at each station (Fig. 5, Table 2). The outputs of these analyses are in good agreement and may be considered simultaneously in order to summarize the results of this study.

A two-way coincidence table (Table 2) was derived from cross classification of species and site clusters at the 0.700 level of similarity $\left(C_{\bar{\lambda}}\right)$. The nekton community in each habitat was clearly differentiated by this approach. The $C_{\lambda}$ value for overlap between the grass bed sites and the two marsh stations was only 0.534 . This value highlights the basic differences between

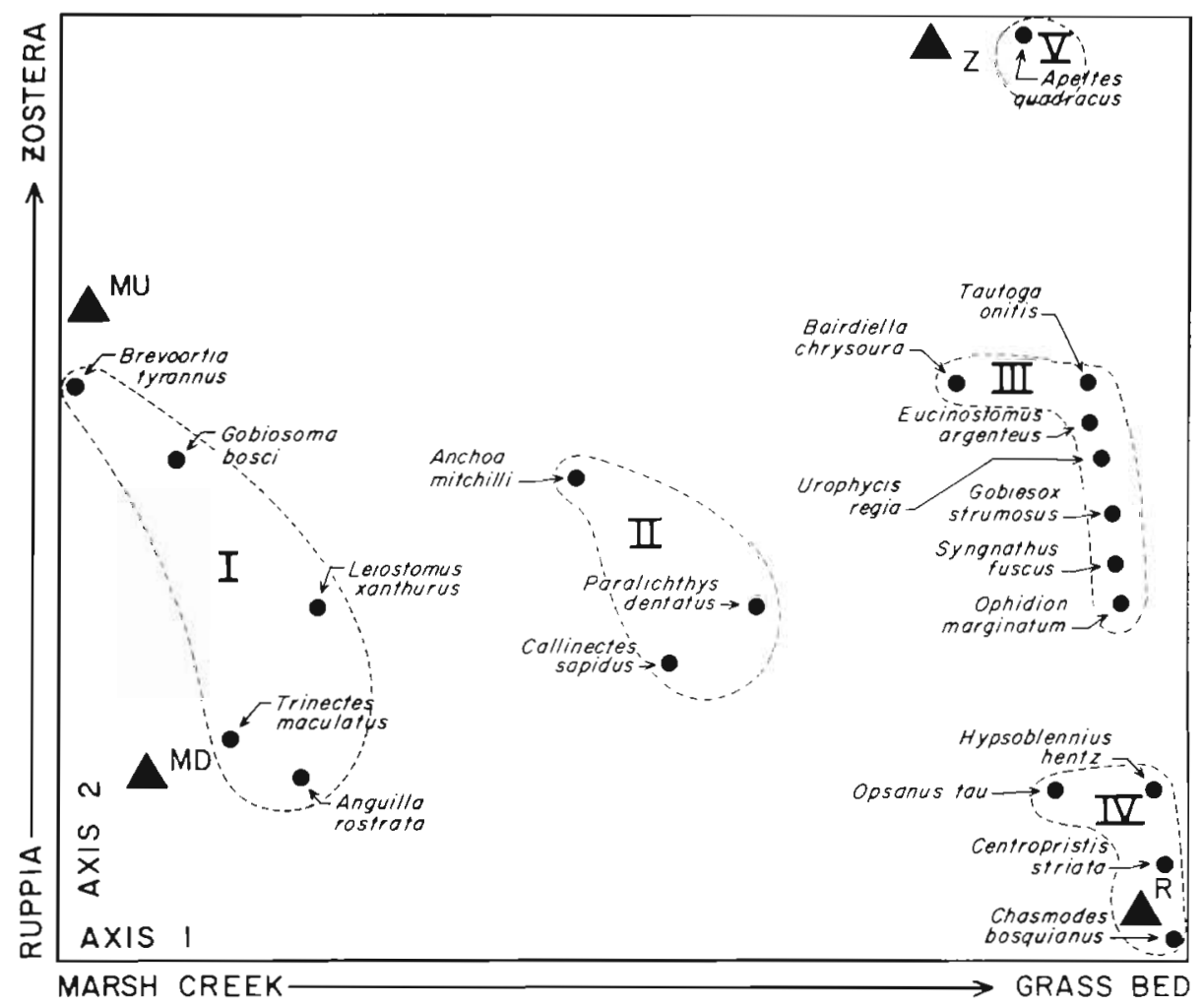

Fig. 5. Species distribution along the tidal creek-seagrass meadow coenocline as depicted by reciprocal averaging ordination. Principal axis I accounted for $85.2 \%$ of the total variance and was associated with distributions of species among habitats. Axis II described $7.9 \%$ of the total variance and was related to the microhabitat preferences of several species within the grassbed. Only species represented by 15 or more individuals in all collections are plotted. Station symbols locate each sampling site in ordination space. As expected, the tidal creek stations are more closely related in species composition and abundance than are the 2 grassbed stations. Group designations I-V were fitted by eye. MU Marsh Upstream; MD Marsh Downstream; Z Zostera and R Ruppia stations, respectively 
Table 2. Two-way coincidence table comparing station (Groups A and B) and species (Groups I-VII) associations at Vaucluse Shores, Virginia. Clustering by flexible sorting strategy, $\beta=-0.25$; similarity index $C \lambda$ (Morisita, 1959), all data untransformed

\begin{tabular}{|c|c|c|c|c|c|}
\hline & \multirow[b]{2}{*}{ Species } & \multicolumn{2}{|c|}{ A } & \multicolumn{2}{|c|}{$\mathrm{B}$} \\
\hline & & Zostera & Ruppia & $\begin{array}{l}\text { Marsh } \\
\text { Upstream }\end{array}$ & $\begin{array}{c}\text { Marsh } \\
\text { Downstream }\end{array}$ \\
\hline $\mathrm{I}$ & Anchoa mitchilli & 139 & 104 & 183 & 69 \\
\hline II & $\begin{array}{l}\text { Paralichthys dentatus } \\
\text { Callinectes sapidus }\end{array}$ & $\begin{array}{r}71 \\
1004\end{array}$ & $\begin{array}{r}78 \\
1409\end{array}$ & $\begin{array}{r}5 \\
661\end{array}$ & $\begin{array}{r}62 \\
1282\end{array}$ \\
\hline III & $\begin{array}{l}\text { Leiostomus xanthurus } \\
\text { Anguilla rostrata } \\
\text { Trinectes maculatus }\end{array}$ & $\begin{array}{r}3794 \\
3 \\
2\end{array}$ & $\begin{array}{r}3270 \\
6 \\
6\end{array}$ & $\begin{array}{r}11307 \\
7 \\
16\end{array}$ & $\begin{array}{r}14354 \\
36 \\
48\end{array}$ \\
\hline IV & $\begin{array}{l}\text { Brevoortia tyrannus } \\
\text { Gobiosoma bosci }\end{array}$ & 2 & 3 & $\begin{array}{r}390 \\
29\end{array}$ & $\begin{array}{r}38 \\
7\end{array}$ \\
\hline V & $\begin{array}{l}\text { Eucinostomus argenteus } \\
\text { Urophycis regia } \\
\text { Syngnathus fuscus } \\
\text { Gobiesox strumosus } \\
\text { Ophidion marginatum }\end{array}$ & $\begin{array}{r}12 \\
13 \\
753 \\
6 \\
36\end{array}$ & $\begin{array}{r}8 \\
10 \\
871 \\
10 \\
46\end{array}$ & & 8 \\
\hline VI & $\begin{array}{l}\text { Tautoga onitis } \\
\text { Bairdiella chrysoura } \\
\text { Apeltes quadracus }\end{array}$ & $\begin{array}{r}13 \\
123 \\
105\end{array}$ & $\begin{array}{r}7 \\
64 \\
2\end{array}$ & 16 & 11 \\
\hline VII & $\begin{array}{l}\text { Hypsoblennius hentzi } \\
\text { Opsanus tau } \\
\text { Centropristis striata } \\
\text { Chasmodes bosquianus }\end{array}$ & $\begin{array}{r}19 \\
15 \\
8 \\
2\end{array}$ & $\begin{array}{l}53 \\
45 \\
33 \\
16\end{array}$ & & \\
\hline
\end{tabular}

the 2 communities which largely resulted from 2 factors. First, common species in both areas had centers of abundance clearly associated with only 1 of the 2 habitats. Leiostomus xanthurus and Trinectes maculatus were in this category. Secondly, a large variety of species recruited to the Chesapeake Bay in late summer are apparently seagrass specialists and are not abundant in marsh habitats. These species are listed in Table 2 within Groups V to VII.

Other salient features of Table 2 may be summarized as follows. Anchoa mitchilli (Group I) was rather evenly distributed among habitats, a characteristic pattern for this ubiquitous estuarine resident. Although abundant, species in Group II were not quite so evenly distributed. Members of Group III exhibited a general preference for the marsh habitat, while Group IV contained 2 species clearly preferring the tidal creek

Species which apparently preferred the seagrass meadow include taxa appearing in Groups $\mathrm{V}$ to VII. The species most evenly distributed across seagrass microhabitats (Zostera vs. Ruppia) were found in Group V; 3 species in Group VI were more abundant in the Zostera zone whereas members of Group VIr frequented the Ruppia station.

The results of the RA ordination were qualitatively identical to that of the independent classification procedure. Axes 1 and 2, of the ordination accounted for
$93 \%$ of the variance in the data set. To facilitate further discussion, we have constructed boundaries around several groups appearing in Fig. 5. It should be emphasized that these were fitted by eye, and result in apparent discontinuities in what are otherwise continuous distributions among habitats for many species. However, by comparing these groups to those appearing in the two-way coincidence table (Table 2), it is obvious that they are in close accordance with the clusters produced by the less subjective classification method. Two general patterns emerge from the ordination diagram, the first principal axis separates species along the marsh creek - seagrass meadow coenocline, the second (accounting for $8 \%$ of the total variance) ordinates species across microhabitat gradients in the seagrass meadow. Species 'preferring' marsh habitats are designated to the left of Fig. 5 as Group I. Leiostomus xanthurus is included here because this species was more abundant in the marsh creek by a nearly $4: 1$ margin over the seagrass meadow (Tables 1 and 2 , Fig. 6). Species in Group II were spread rather uniformly among sites (more so than other species) and are, therefore, considered to be ubiquitous members of both habitats. Although Callinectes sapidus were slightly more abundant in the seagrass meadows, especially from late summer into the fall, they are considered members of this group.

The remaining species in Fig. 5 were most heavily 
represented in seagrass collections. They are distributed in 3 groups (III, IV and V) along the second principal axis and are believed to represent a gradient in microhabitat selection in the seagrass meadow from the Zostera into the Ruppia zone. Opsanus tau, Hypoblennius hentzi, Centropristis striata, and Chasmodes bosquianus (Group IV) were most abundant at the Ruppia station while Apeltes quadracus predominated in the Zostera stand (Group V). Species evenly distributed between seagrass microhabitats are shown in Group III. Because relatively few species were abundant in our collections (only 3 species comprised $90 \%$ of the total catch in the seagrass meadow) we must express caution in extrapolating our results into generalizations whether they involve comparisons across habitats or within microhabitats. This is especially true for species which fall into Groups IV and V (Fig. 5) and although the generic patterns are judged real, it is possible that they might change with more intense sampling or among years. Previous reports of microhabitat preferences by several species inhabiting grass beds, however, have recently appeared (Stoner and Livingston, 1980; Stoner, in press), and Heck and Thoman (1981) and Lascara (1981) have recently discussed the relative values of different seagrass densities and foliose (Ruppia) vs. simple (Zostera) plant types as predation refugia for grass shrimps and fishes.

\section{Nursery comparisons}

Habitat preferences for abundant species at Vaucluse Shores were established in previous sections (Fig. 6, Table 2). Monthly breakdowns for the six dominant finfishes in our catch are shown in Table 3. Menidia menidia has been added to this list because of its abundance in Wegener ring collections. The combined data set for the 2 sampling methods confirms our

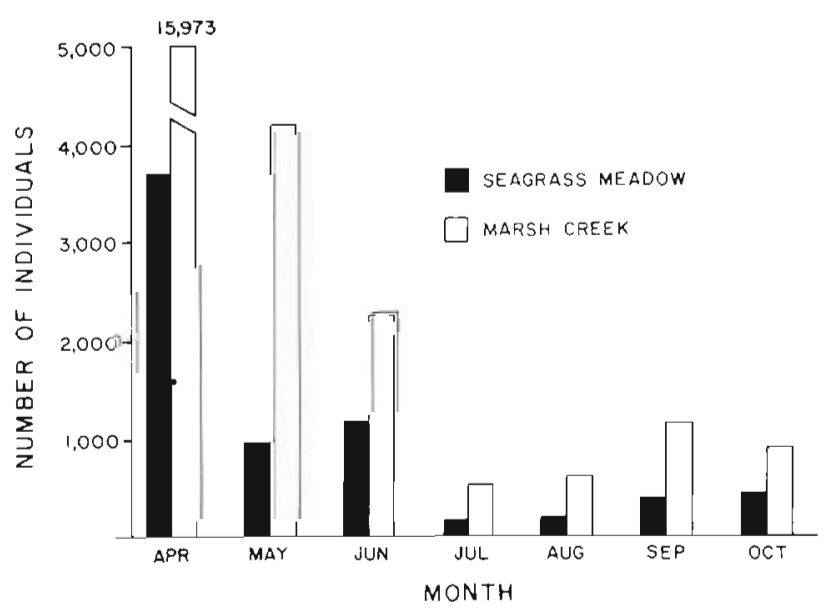

Fig. 6. Total numbers of spot (Leiostomus xanthurus) captured in monthly samples at the tidal creek and grassbed study sites

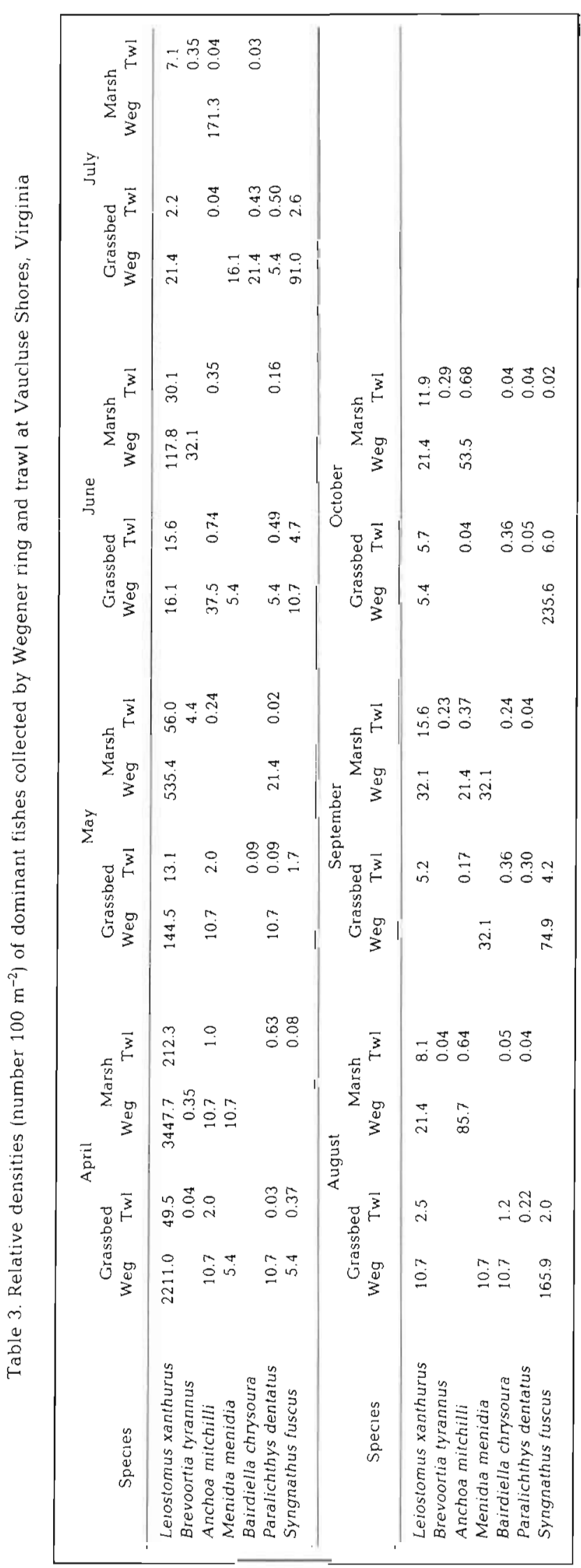


earlier comments about the distributional ecology of these species but provides additional details of their temporal distributions. We previously alluded to the observation that Syngnathus fuscus was a grassbed specialist. Only $0.5 \%$ of the entire catch of this species was taken in the marsh. Young individuals were abundant in Wegener ring collections in late summer and fall when postlarvae and very early juveniles were recruited to the gear. Other common species in the grass bed samples were Bairdiella chrysoura and after May, Paralichthys dentatus (postlarvae were apparently randomly distributed among habitats). Although M. menidia was not captured by the trawl, its abundance in the Wegener ring collections as adults was higher in the grass bed.

The Wegnener ring collections also confirm the rather uniform, albeit patchy, distribution of juvenile Anchoa mitchilli, a species which is notoriously ubiquitous in most estuarine habitats, including open waters. Another water-column feeder, Brevoortia tyrannus, however, was only taken once in the marsh with the Wegener ring, although its distribution in the overall catch (and virtual absence over the grass bed) places it in the marsh preference category. As youngof-year, this species has a widespread distribution in the estuary, nonetheless, as smaller individuals (40 to $70 \mathrm{~mm}$ standard length, SL) they tend to frequent marshy habitats, especially in brackish water (June and Chamberlain, 1959; Pachecho and Grant, 1965; Dahlberg, 1972; Weinstein, 1979; Weinstein et al., 1980).

The overwhelming abundance of Leiostomus xanthurus in our collections allowed us to undertake a detailed analysis of habitat preference for young of this species. Throughout the study period, L. xanthurus were significantly more abundant (Wilcoxon sign-rank test; $\mathrm{p}<0.05$ ) in marsh collections than in the grassbed (Fig. 6, Table 3). Length frequency distributions for each habitat for this species are shown in Fig. 7 and comparisons between means and their associated variances are listed in Table 4. The data are remarkably clear in depicting events during the nursery utilization phase of this species. Early in the year (April-May), L. xanthurus were 4.3 times more abundant in the tidal creek compared to the grassbed. Furthermore, they were significantly larger in the creek during this period (Table 4). In June, however, means lengths did not differ in both habitats, but thereafter, L. xanthurus were significantly smaller in the tidal creek. Throughout the year, the variance around mean length (with one exception) also was significantly greater in the seagrass meadow (Table 4). We interpret these combined observations as follows.

The preferred habitat for the earliest life stage (susceptible to capture) is the marsh creek. This population is generally homogenous for length although this may be partly a sampling artifact. For example, a new wave of recruits entered the grass bed in May as evidenced by the secondary peak of smaller length individuals (Fig. 7). Yet on this same date, very few of this cohort were captured in the marsh. The larger variance of the mean associated with length frequency distributions in the grassbed after recruitment ceased (end of May), nonetheless, is deemed real and, we believe, represents waves of non-resident individuals passing
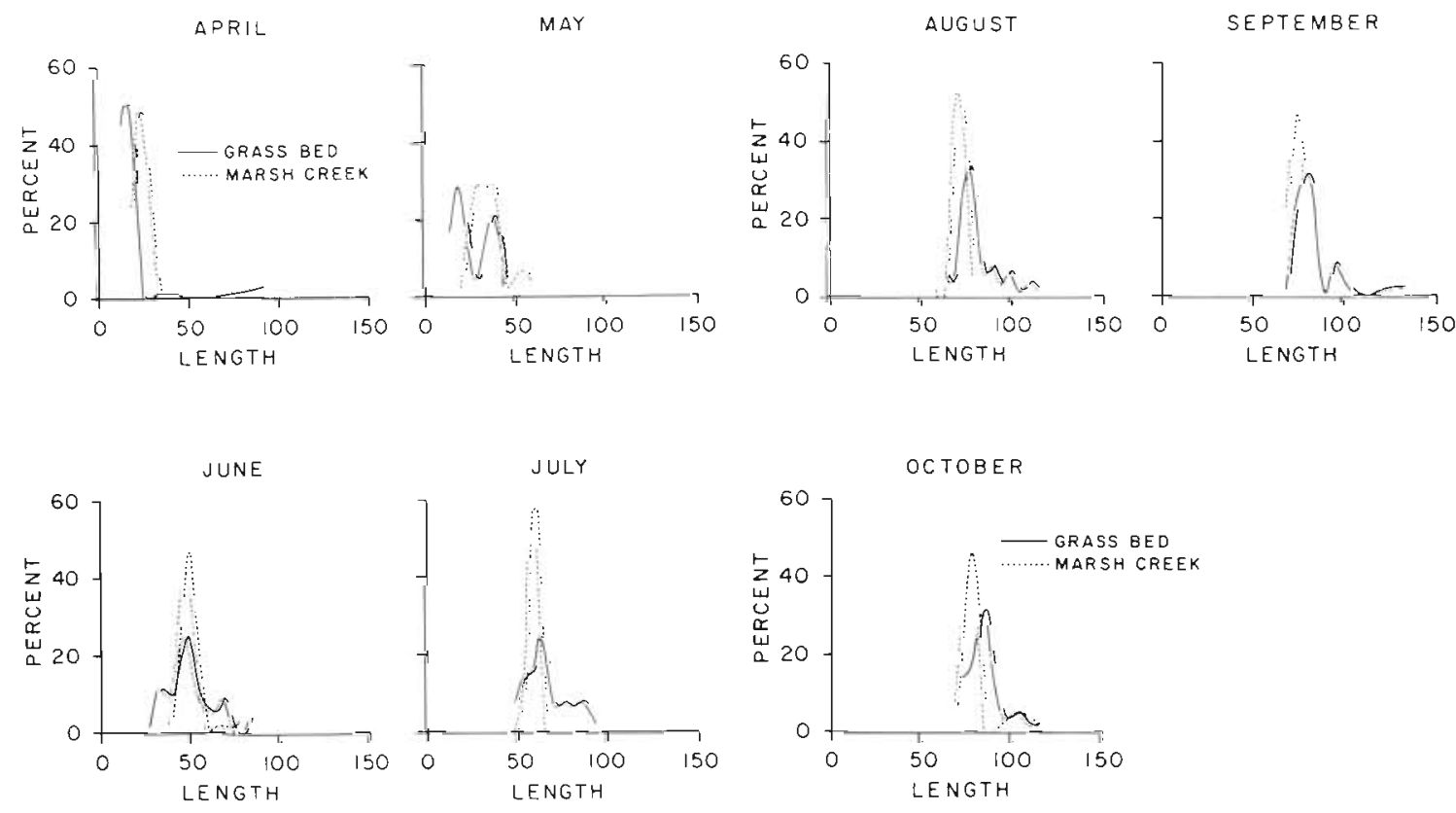

Fig. 7. Monthly length frequency distributions for spot (Leiostomus xanthurus) captured at the tidal creek and grassbed study sites. Length intervals are grouped in $5 \mathrm{~mm}$ SL increments 
Table 4. Comparison of monthly length frequency distributions for spot Leiostomus xanthurus, collected in marsh creek and seagrass habitats. One tailed t-test; ${ }^{*}=$ significant at $\alpha=0.05$

\begin{tabular}{|c|c|c|c|c|c|c|c|c|c|c|c|}
\hline Month & Habitat & $\mathrm{n}$ & $\begin{array}{c}\text { Mean } \\
\text { length } \\
\text { (mm) }\end{array}$ & $\mathrm{F}$ & $\mathrm{t}$ & Month & Habitat & $\mathrm{n}$ & $\begin{array}{c}\text { Mean } \\
\text { length } \\
\text { (mm) }\end{array}$ & $\mathrm{F}$ & $\mathrm{t}$ \\
\hline Apr & $\begin{array}{l}\text { Marsh } \\
\text { Seagrass }\end{array}$ & $\begin{array}{l}60 \\
70\end{array}$ & $\begin{array}{l}28.6 \\
21.1\end{array}$ & $2.21^{\circ}$ & $-13.44^{\prime}$ & May & $\begin{array}{l}\text { Marsh } \\
\text { Seagrass }\end{array}$ & $\begin{array}{l}46 \\
56\end{array}$ & $\begin{array}{l}39.9 \\
30.2\end{array}$ & 1.59 & $-5.84^{\circ}$ \\
\hline Jun & $\begin{array}{l}\text { Marsh } \\
\text { Seagrass }\end{array}$ & $\begin{array}{l}59 \\
59\end{array}$ & $\begin{array}{l}55.4 \\
55.3\end{array}$ & $2.72^{\circ}$ & 0.017 & Jul & $\begin{array}{l}\text { Marsh } \\
\text { Seagrass }\end{array}$ & $\begin{array}{l}62 \\
62\end{array}$ & $\begin{array}{l}63.4 \\
71.4\end{array}$ & $4.20^{\circ}$ & $4.93^{\circ}$ \\
\hline Aug & $\begin{array}{l}\text { Marsh } \\
\text { Seagrass }\end{array}$ & $\begin{array}{l}60 \\
62\end{array}$ & $\begin{array}{l}74.9 \\
85.3\end{array}$ & $11.69^{\circ}$ & $7.17^{\circ}$ & Sep & $\begin{array}{l}\text { Marsh } \\
\text { Seagrass }\end{array}$ & $\begin{array}{l}62 \\
60\end{array}$ & $\begin{array}{l}78.3 \\
87.6\end{array}$ & $12.79^{\circ}$ & $6.24^{\circ}$ \\
\hline Oct & $\begin{array}{l}\text { Marsh } \\
\text { Seagrass }\end{array}$ & $\begin{array}{l}60 \\
60\end{array}$ & $\begin{array}{l}82.2 \\
90.1\end{array}$ & $2.03^{\circ}$ & $5.65^{\circ}$ & & & & & & \\
\hline
\end{tabular}

through the seagrass meadow. That these may be mostly larger individuals moving out of the primary nurseries (tidal creeks) is established by the larger average individual found in the bed after June. Apparently, the tidal creeks provide an optimum habitat for postlarvae and early juveniles which tend to move downstream with increasing size (see also Herke, 1971; Purvis, 1976)

The lack of residency in the grassbed is confirmed by the results of Orth and Heck (1980) and Brooks et al. (unpubl.) which depicted random, but equal, distributions of Leiostomus xanthurus in the seagrass meadows and nearby unvegetated areas (both day and night). During our study period, however, overall abundance in the creek was 3.6 times greater than in the bed, with larger individuals continuously 'bleeding off' into downstream areas. Similar patterns of nursery utilization have been predicted for this and other species (e.g. Herke, 1971; Purvis, 1976); our results provide a particularly striking example of what constitutes the primary nursery habitat for one of the most abundant estuarine species along the Atlantic and Gulf coasts.

\section{DISCUSSION}

To our knowledge, this study represents the first attempt to make direct comparisons between the 2 major primary nurseries of temperate latitude estuaries, i.e. tidal marsh creeks and seagrass meadows. It is noteworthy that the habitats we sampled were immediately adjacent because recruitment into the area was likely a random process (for most species) and differences in the composition of the nekton community should, therefore, be largely due to habitat selection and preference.

Some recent attention, however, has been given to patterns of distribution of estuarine species which are ascribed to differential mortality (Polgar, 1982). Wein- stein and Walters (1981) reported a similar phenomenon for Leiostomus xanthurus in the Cape Fear estuary, North Carolina, where mortality on the young of this species was significantly (or nearly significantly) higher in polyhaline tidal creeks compared to other portions of the estuary. The difference was attributed to greater numbers of stenohaline marine predators seasonally occupying the polyhaline marshes. Similarly, predation seems to influence the composition of the grassbed community compared to surrounding areas. For example, the role of grassbeds in providing predation refugia for several species of invertebrates and fishes has been recently documented (Nelson, 1979; Coen et al., 1981; Heck and Thoman, 1981; Lascara, 1981) and considered along with food availability (Miller and Dunn, 1980) predation may be a major structuring force that produces the nekton community characteristic of each habitat. Such interactions have recently been discussed by Mittelbach (1981) who examined feeding energetics of the bluegill Lepomis macrochirus. He comments that bluegills $<100 \mathrm{~mm}$ feed on Daphnia occurring within a few meters of the vegetation while apparently ignoring opportunities to feed on Daphnia located farther offshore suggests that these fish may balance foraging profitability and predation risk when selecting habitats, and that this balance is a dynamic one depending on prey availability and relative risks.' He further states, 'a size-specific trade-off between foraging profitability and predation risk is likely to be a common phenomenon among many groups of organisms whose populations are structured by body size.' Thus, the 'ground rules' (community structuring forces) may be the same in each habitat except that in order to make use of the full spectrum of available resources some species have evolved specialization for one habitat over another.

Even without direct comparisons, it is hard to accept the fact that overall food availability is lower in the 
tidal creek compared to the seagrass meadow. To what, then, can the significant differences in species diversity in the grassbed versus the adjacent tidal creek for probably for that matter, everywhere that seagrass meadows and marshes co-occur-e.g. Livingston, 1975) be attribute? We concur with Orth and Heck (1980) that structural complexity of the habitat probably plays an important role. Apparently, the tidal creeks do not attain the same degree of complexity (per unit area) as the seagrass meadow. These considerations are similar to the role of increased heterogeneity with in seagrass habitats discussed by Weinstein and Heck (1979) and Heck and Orth (1980b). Here additions to the 'simple' meadows of higher latitudes by algal windrows and sponges (midlatitudes) and coral patches and calcareous algae (low latitudes) are thought to be major contributors to species richness. In the present study, fine-scale (microhabitat) differences between the Ruppia and Zostera zones, in the form of sand-interspersed patches in the Ruppia bed (spatial heterogeneity), along with the greater structural complexity of this grass species, may have contributed to greater species richness in this microhabitat (see also Stoner, in press).

We are acutely (perhaps painfully) aware that all of our comparisons do not include experimental data. Our collective experience, however, dictates our belief that the patterns we describe are 'real', at least we see them repeated in time and space (including widely separated estuaries), as do others. It is perhaps fortunate that insofar as the nekton communities of estuaries are concerned that we are not overburdened by a 'surplus of hypotheses' (Hairston, 1980). We hope that our own ideas, as presented here, will be amenable to future testing. We ourselves are attempting to move in this direction.

One of the most striking features of our study is the notable absence of transient (marine) species that are dependent on polyhaline, shallow nursery habitats in the Chesapeake Bay (a parallel conclusion was drawn by Heck, pers. commun.). In Panama, Weinstein and Heck (1979) listed 10 species, mostly members of the families Lutjanidae, Serranidae and Pomadasyidae, which as postlarvae and early juveniles made extensive use of turtlegrass (Thalassia testudinum) meadows. As adults these species are predaceous reef forms capable of reaching considerable size. Florida seagrass meadows are also characterized by many transient species whose young utilize this habitat (Livingston, 1975; Weinstein et al., 1977). More notable members of this group include: Lagodon rhomboides, Orthopristis chrysoptera, Centropristis melana, Leiostomus xanthurus, Bairdiella chrysoura, Cynoscion nebulosus and Calamus arctifrons. Unlike Panama, however, the majority of these species are relatively small and shortlived as adults. The list is also similar for eelgrass meadows in North Carolina (Adams, 1976a,b). In Gulf coast and North Carolina salt marshes, however, Leiostomus xanthurus, young mugilids (Mugil spp.), menhaden (Brevoortia spp.), Micropogonias undulatus (in estuaries lacking extensive deep channels), eels (Anguilla, Myrophis) and Symphurus plagiusa are seasonally abundant, often reaching extremely high densities (Herke, 1971; Parker, 1971; Weinstein, 1979; Weinstein et al., 1980).

Polyhaline seagrass meadows and tidal creeks at Vaucluse Shores, on the other hand, were characterized by relatively few regional species making extensive nursery usage of these habitats. Ophidion marginata, Urophycis regia, and Centropristis striata were only present as larger juveniles for a brief period during late summer and fall. Their generally low numbers indicates that they were probably not residents of the area, but were likely making feeding forays into the shallows. Other 'stragglers' making limited use of the Zostera-Ruppia meadows were juvenile Lagodon rhomboides, Stenotomus chrysops, Tautoga onitis, and Orthopristis chrysoptera. Several additional 'southern' forms were represented by just a few specimens. Bairdiella chrysoura, present in intermediate numbers, is also near the northern edge of its range in the Chesapeake Bay and although abundant in some years is relatively rare in others. It is also clear from many studies in the riverine channels of the lower Chesapeake, that Cynoscion regalis and Micropogonias undulatus generally prefer deeper waters as postlarvae and early juveniles (Haven, 1957; Markle, 1976; Chao and Musick, 1977). However, both species will enter tidal creeks as older juveniles, especially in brackish water.

The nekton apparently most dependent on shallow waters of the saline portion of the Chesapeake Bay are Leiostomus xanthurus, Callinectes sapidus and Paralichthys dentatus. Although abundant baywide as late juveniles, most Brevoortia tyrannus seem to spend their earliest days in oligohaline portions of the system. Anchoa mitchilli, while not as salinity dependent as menhaden postlarvae, generally fall into a similar category. On the basis of our collective efforts, we suggest that $L$. xanthurus is most successful in tidal creek habitats, especially in mesohaline marshes (Weinstein, 1979; Weinstein et al., 1980). Although very young (15 to $30 \mathrm{~mm}$ ) C. sapidus were widespread throughout the study area, more juveniles were captured in the seagrass meadow in late summer and fall. Much the same pattern was observed for $P$. dentatus and may be a general phenomenon for several species which seem to 'gravitate' to the grassbed late in the year. An important phenomenon that we have observed is the mid-summer decline in abundance by 
many species in the shallows. Their fate as they move out of the marshes and off the bed into deeper waters is unknown, but it is expected that predation pressure would be particularly high at this time.

A fruitful area for future investigation is the means by which transient species 'choose' their optimum habitat and the adaptive values associated with this choice. The paucity of 'hard data' in this area is especially striking. Although it is dogmatic that shallow estuarine habitats serve as nurseries for the young of many marine species, it is also clear from this and other recent studies that we are just beginning to unravel the details of the processes of habitat selection and utilization.

Acknowledgements. C. Abernathy and T. Stabel provided extensive aid in the field. J. Olney and R. Orth offered constructive criticism on earlier versions of the manuscript. We appreclate their collective efforts. This study was înded in part by a faculty grant-in-aid to the senior author from Virginia Commonwealth University. Additional funding was provided by EPA Grant R 808707 (to MPW). Logistical support was also provided by the Virginia Institute of Marine Science.

\section{LITERATURE CITED}

Adams, S.M. (1976a). The ecology of eelgrass, Zostera marina (L.) fish communities. I. Structural analysis. J. exp. mar. Biol. Ecol. 22: 269-291

Adams, S. M. (1976b). The ecology of eelgrass, Zostera marina (L.) fish communities. II. Functional analysis. J. exp. mar. Biol. Ecol. 22: 293-311

Arnoldi, D. C., Herke, W. H., Clairain, E. J., Jr. (1974). Estimate of growth rate and length of stay in a marsh nursery of juvenile Atlantic croaker Micropogon undulatus (Linnaeus), 'sandblasted' with fluorescent pigments. Gulf Carribb. Fish Inst. Proc. 26th Ann. Sess., p. 158-172

Chao, L. N., Musick, J. A. (1977). Life history, feeding habits, and functional morphology of juvenile sciaenid fishes in the York River estuary, Virginia. Fish. Bull. U. S. 75: $657-702$

Clifford, H. T., Stephenson, W. (1975). An introduction to numerical classification. Academic Press, New York

Coen, L. D., Heck, K. L., Jr., Abele, L. G. (1981). Experiments on competition and predation among shrimps of seagrass meadows. Ecology 62: 1484-1493

Dahlberg, M. D. (1972). An ecological study of Georgia coastal fishes. Fish. Bull. U. S. 70: 323-353

Del Moral, R. (1980). On selecting indirect ordination methods. Vegetatio 42: 75-84

Gauch, H. G., Whittaker, R. H., Wentworth, T R. (1977). A comparative study of reciprocal averaging and other ordination techniques. J. Ecol. 65: 157-174

Hairston, N. G. (1980). Species packing in the salamander genus Desmognathus. What are the interspecific interactions involved? Am. Nat. 115: 354-366

Haven, D. S. (1957). Distribution, growth, and availability of juvenile croaker, Micropogon undulatus, in Virginia. Ecology 38: 88-97

Heck, K. L., Jr., Orth, R. J. (1980a). Structural components of eelgrass (Zostera marina) meadows in the lower Chesapeake Bay - Decapod crustacea. Estuaries 3: 289-295
Heck, K. L., Jr., Orth, R. J. (1980b). Seagrass habitats: the roles of habitat complexity, competition and predation in structuring associated fish and motile macroinvertebrate assemblages. In: Kennedy, V. S. (ed.) Estuarine perspectives. Academic Press, New York, p. 449-464

Heck, K. L., Jr., Thoman, T. A. (1981). Experiments on predator-prey interactions in vegetated aquatic habitats. J. exp. Mar. Biol. Ecol. 53: 125-134

Herke, W. H. (1971). Use of natural, and semi-impounded, Lousiana tidal marshes as nurseries for fishes and crustaceans. Ph. D. thesis, Louisiana State University

Hill, M. O. (1973). Reciprocal averaging: an eigenvector method of ordination. J. Ecol. 61: 237-249

June, F. C., Chamberlain, J. L. (1959). The role of the estuary in the life history and biology of Atlantic menhaden. Proc. Gulf Carrib. Fish. Inst., 11th Ann. Sess., p. 41-45

Kjelson, M. A., Johnson, G. N. (1978). Catch efficiencies of a 6.1-meter otter trawl for estuarine fish populations. Trans. Am. Fish Soc. 107: 246-254

Knudsen, E. E., Herke, W. H. (1978). Growth rate of marked juvenile Atlantic croakers, Micropogon undulatus, and length of stay in a coastal marsh nursery in southwest Louisiana. Trans. Am. Fish Soc. 107: 12-20

Lance, G. N., Williams, W. T. (1967). A general theory of classificatiory sorting strategies. I. Hierarchical systems. Computer J. 10: 373-380

Lascara, V. J. (1981). Fish predator-prey interactions in areas of eelgrass (Zostera marina). M. S. thesis, College William and Mary

Livingston, R. J. (1975). Impact of Kraft pulp-mill effluents on estuarine and coastal fishes in Apalachee Bay, Florida, USA. Mar. Biol. 32: 19-48

Loesch, H. J., Bishop, A., Crowe, A., Kuckyr, R., Wagner, P. (1976). Technique for estimating trawl efficiencies in catching brown shrimp (Penaeus aztecus), Atlantic croaker (Micropogon undulatus) and spot (Leiostomus xanthurus). Gulf Res. Rep. 5: 29-33

Markle, D. F. (1976). The seasonality of availability and movements of fishes in the channel of the York River, Virginia. Chesapeake Sci. 17: 50-55

Miller, J. M., Dunn, M. L. (1980). Feeding strategies and patterns of movement in juvenile estuarine fishes. In: Kennedy, V.S. (ed.) Estuarine perspectives. Academic Press, New York, p. 437-448

Mittelbach, G. G. (1981). Foraging efficiency and body size: a study of optimal diet and habitat use by bluegills. Ecology 62: $1370-1386$

Morisita, M. (1959). Measurement of interspecific association and similarity between communities. Mem. Fac. Kyushu. Univ., Ser. E (Biol.) 3: 65-80

Nelson, W. G. (1979). Experimental studies of selective predation on amphipods: consequences for amphipod distribution and abundance. J exp. mar. Biol. Ecol. 38: 225-245

Orth, R. J., Heck, K. A., Jr. (1980). Structural components of eelgrass (Zostera marina) meadows in the lower Chesapeake Bay - Fishes. Estuaries 3: 278-288

Pachecho, A. L., Grant, G. C. (1965). Studies of the early life history of Atlantic menhaden in estuarine nurseries. Part I. Seasonal occurrence of juvenile menhaden and other small fishes in a tributary creek of Indian River, Delaware. Spec. scient. Rep. U. S. Fish Wildl. Serv. (Fisheries) 504: $1-32$

Parker, J. C. (1971). The biology of the spot, Leiostomus xanthurus Lacepede, and the Atlantic croaker, Micropogon undulatus (Linnaeus), in two Gulf of Mexico nursery areas. Ph. D. thesis, Texas A and M University 
Polgar, T T. (1982). Larval retention: transport and behavior or differential mortality? Estuarine Research Federation Conf., Gleneden Beach, Oregon (Abstract)

Purvis, C. (1976). Nursery area survey of northern Pamlico Sound and tributaries. Div. Mar. Fish Rept. (prepared for U. S. Dept. Comm., NOAA, Natl. Mar. Fish Ser.), p. 62

Rosenzweig, M. L. (1974). On the evolution of habitat selection. In: Cave, A. J. (ed.) Proc. First Inter, Cong. Ecol Pudoc, Wageningen, p. 401-404

Simpson, E. H. (1949). Measurement of diversity. Nature, Lond. 163: 688

Stoner, A. W. (in press). Distribution of fishes on seagrass meadows: role of macrophyte biomass and species compositon. Fish. Bull. U. S.

Stoner, A. W., Livingston, R. J. (1980). Distributional ecology and food habits of the banded blenny, Paraclinus fasciatus (Clinidae): a resident in a mobile habitat. Mar. Biol. 56: 239-246

Wegener, W. (1976). Sampling shallow water fish populations using the Wegener ring. S. E. Game Fish Comm., Ann. Conf., p. 663-673
Weinstein, M. P. (1979). Shallow marsh habitats as primary nurseries for fishes and shellfish, Cape Fear River, North Carolina. Fish. Bull. U. S. 77: 339-357

Weinstein, M. P., Courtney, C. M., Kinch, J. C. (1977). The Marco Island estuary: a summary of physicochemical and biological parameters. Fla Scient. 40: 97-124

Weinstein, M. P., Heck, K. L., Jr. (1979). Ichthyofauna of seagrass meadows along the Gulf of Mexico: composition, structure and community ecology. Mar. Biol. 50: 97-107

Weinstein, M. P., Walters, M. F. (1981). Growth, survival and production in young-of-year populations of Leiostomus xanthurus Lacepede residing in tidal creeks. Estuaries 4: 185-197

Weinstein, M. P., Weiss, S. L., Walters, M. F. (1980). Multiple determinants of community structure in shallow marsh habitats, Cape Fear River estury, North Carolina. Mar. Biol. 58: 227-243

Yakupzack, P. M., Herke, W. H., Perry, W. G. (1977). Emigration of juvenile Atlantic croakers, Micropogon undulatus, from a semi-impounded marsh in southwestem Louisiana. Trans. Am. Fish. Soc. 106: 538-544

This paper was presented by Professor M. R. Carriker; it was accepted for printing on November 24, 1982 